\title{
THE WPA AND THE ABUSE OF PSYGHIATRY
}

The following letter has been received by the College from Professor Peter Berner, Secretary-General of the World Psychiatric Association:

Dear Colleagues,

As you will recall, the World Psychiatric Association's General Assembly at its meeting in Honolulu in August 1977, adopted a resolution to establish a Committee to Review the Abuse of Psychiatry for political reasons.

In January 1978, the Executive Committee of the WPA at a meeting in New Delhi, decided to set up a 'Legal Sub-Committee', whose first task would be to propose procedure for the Committee to be newly established. This Sub-Committee is composed of three international jurists: The chairman is $\mathbf{M r} \mathbf{A}$. McNulty (UK), who is director of the British Institute of Human Rights. The other two members are Dr K. A. Norgaard (Denmark) and Mr B. Kiernan (Rep of Ireland), who are both present members of the European Commission of Human Rights.

The Executive Committee at the same time decided to set up an 'Ad hoc Sub-Committee of Psychiatrists' to receive any complaints of such abuse, pending the coming into operation of the dufinitive Committee to Review Abuse of Psychiatry for political reasons. The following persons have agreed to serve on this "Ad hoc Sub-Committee' Prof J.-Y. Gosselin (Canada) who serves as chairman, Prof J. Bastiaans (Netherlands), Prof T. Helgason (Iceland), Prof J. Pogady (Czechoslovakia) and Prof A. Rubim de Pinho (Brazil).

The 'Legal Sub-Committee' has already met and intends to put its proposals to the Executive Com- mittee of the World Psychiatric Association at the next meeting in Cairo, on 2 December 1978.

Until the establishment of the definitive Committee to Review the Abuse of Psychiatry for political reasons, the directives to the "Ad hoc SubCommittee of Psychiatrists' would be the following:

1. To receive any complaints on abuse of psychiatry for political reasons. The complaint should be submitted by a Member Society and addressed to the President of the WPA, through the Secretary General. The Member Society passing on the complaint should not assume a filter function, but forward all written matter concerned with the alleged abuse so far as it is readable and not of an anonymous source. The Secretary General will pass the complaints on to the chairman of the 'Ad hoc Sub-Committee', who will compile documentation on the matter and present a report on their recommendations to the Executive Committee via the Secretary General. The 'Ad hoc Sub-Committee' has no executive authorization. This lies with the Executive Committee of the WPA.

2. The 'Ad hoc Sub-Committee of Psychiatrists' should decide on a method of financial support of the definitive Committee to Review Abuse of Psychiatry for political reasons and should present its suggestions to the Executive Committee at the Cairo meeting.

3. At the Executive Committee meeting in Cairo, the procedure to be adopted by the definitive Committee to Review the Abuse of Psychiatry for political reasons will be decided upon after consideration of the proposals put forward by the 'Legal Sub-Committee' and the 'Ad hoc Sub-Committee of Psychiatrists'.

\section{FORTHCOMING EVENTS}

British Association for Psychopharmacology

The Winter Scientific Meeting will be held at the Royal Society, London, on 4 and 5 December, on the subject of 'The Psychopharmacology of Aggression'. Further details from Dr B. J. Hunt, Programmes Secretary, DHSS Medicines Division, Finsbury Square House, 33-37A Finsbury Square, London EC2A IPP.

\section{Society of Psychiatrists of South Africa}

The Third National Congress will be held at Cape Town University in January 1979 , concurrently with the University's 150th anniversary. The conference will be multi-racial and delegates from a number of African countries are expected. British psychiatrists would be full participants and may present papers and take part in plenary sessions. Further details obtainable from Dr E. W. Shepherd, Secretary of the Study Tours Sub-Committee, Leavesden Hospital, Abbots Langley, Hertfordshire. Group travel arrangements could be made if there is sufficient response.

\section{Introduction to Neuropsychology}

A two-day Conference with the above title will be held at Yorkshire Regional Health Authority headquarters, Leeds, on 10 and 11 May 1979 (provisional dates). Preliminary programme from Mrs U. Holden, Chairman of the Yorkshire Division of Clinical Psychology, Clinical Psychology Office, St James's University Hospital, Leeds LS9 7 TF. 